\title{
FAKTOR PENENTU PROFITABILITAS \\ BANK UMUM SYARIAH DI INDONESIA \\ (Pasca Peralihan Tugas Pengawasan Perbankan \\ dari BI ke OJK)
}

\author{
Fitra Rizal \\ Institut Agama Islam Negeri Ponorogo \\ email: fitrajal@gmail.com
}

Abstract: This research was conducted to determine the determinants of profitability on Sharia Commercial Bank after the transfer of banking supervision duties from Bank Indonesia to the Otoritas Jasa Keuangan. The data used in this research are secondary data obtained from Islamic Banking Statistics published by the Otoritas Jasa Keuangan and Bank Indonesia.The analysis technique used is multiple linear regression using the classic assumption test first. The results of the analysis show that the regression equation used has passed the classic assumption test. This research proves that partially, only the Operational Expenses to Operational Revenue variables that affect Return on Assets of Islamic Commercial Banks in Indonesia for the 2015-2018 Period, while the variable Capital Adequacy Ratio and Inflation did not affect Return on Assets of Sharia Commercial Banks in Indonesia for the 2015-2018 period. And simultaneously the three variables have an effect on Return on Assets of Islamic Commercial Banks in Indonesia for the 2015-2018 Period.

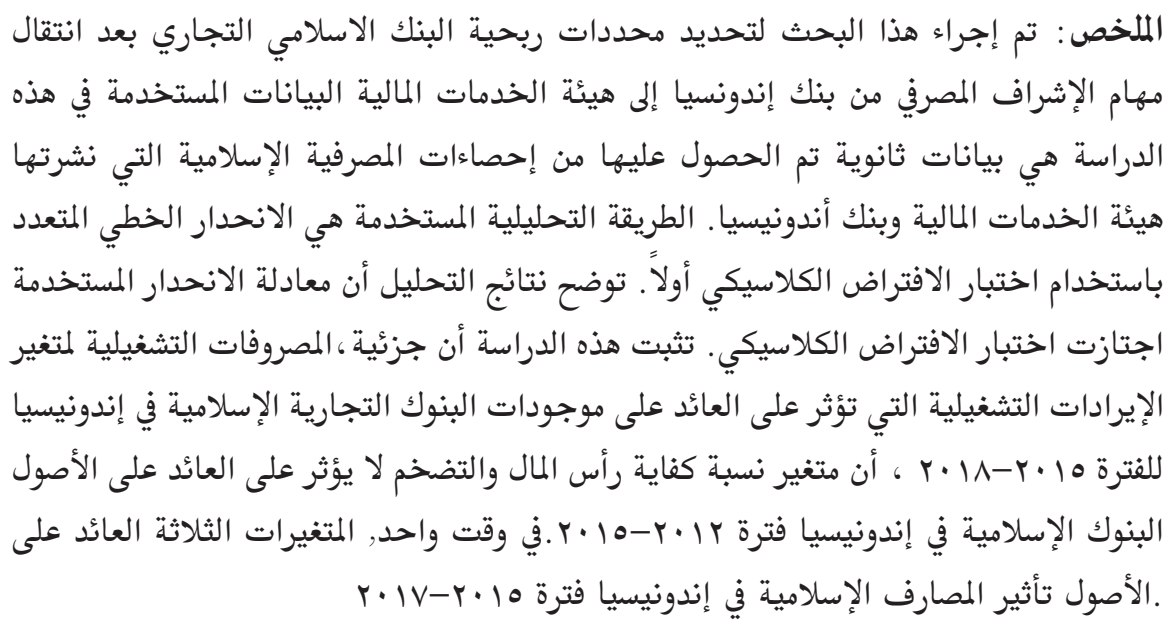


Abtrak: Penelitian inidilakukan untukmengetahuifaktor penentu profitabilitas Bank Umum Syariah pasca peralihan tugas pengawasan perbankan dari Bank Indonesia ke Otoritas Jasa Keuangan. Data yang digunakan dalam penelitian ini adalah data sekunderyang diperoleh dari Statistik Perbankan Syariah yang dipublikasikan oleh Otoritas Jasa Keuangan dan Bank Indonesia. Teknik analisis yang digunakan adalah regresi linier berganda dengan menggunakan uji asumsi klasik terlebih dahulu. Hasil analisis menunjukkan bahwa persamaan regresi yang digunakan telah lolos uji asumsi klasik. Penelitian ini membuktikan bahwa secara parsial, hanya variabel Operational Expenses to Operational Revenue yang berpengaruh terhadap Return on Asset Bank Umum Syariah di Indonesia Periode 2015-2018, sementara variabel Capital Adequacy Ratio dan Inflasi tidak berpengaruh terhadap Return on Asset Bank Umum Syariah di Indonesia Periode 2015-2018. Dan secara simultan ketiga variabel tersebut Berpengaruh terhadap Return on Asset Bank Umum Syariah di Indonesia Periode 2015-2017.

Keyword: capital adequacy ratio, operational expenses to operational revenue, inflasi, return on asset, bank umum syariah

\section{PENDAHULUAN}

Indonesia sudah pernah mengalami krisis keuangan pada tahun 1997-1998, yang disebabkan oleh guncangan di sektor perbankan. Berdasarkan studi dan pengalaman krisis tersebut, pemerintah menilai sistem pengawasan yang tepat bagi Indonesia adalah terintegrasi (unified supervisory model). Sebelum OJK beroperasi, fungsi regulator industri keuangan dijalankan oleh beberapa institusi. Pengawasan dan pengaturan perbankan dijalankan oleh Bank Indonesia (BI), sementara pasar modal dan industri keuangan non bank menjadi tanggung jawab Badan Pengawas Pasar Modal dan Lembaga Keuangan (BapepamLK). Maka sejak 31 Desember 2013, OJK secara resmi mengambil alih fungsi pengawasan industri keuangan bank dan non bank di Indonesia, sehingga BI akan fokus pada pengendalian inflasi dan stabilitas moneter. ${ }^{1}$

${ }^{1}$ http://ojk.go.id 
Hal tersebut dinilai perlu dilakukan karena globalisasi telah menyebabkan kemajuan dan inovasi yang berujung pada sistem keuangan yang kompleks serta saling terintegrasi, seperti adanya lembaga keuangan yang memiliki hubungan kepemilikan di berbagai sub-sektor keuangan. Dengan kebijkan tersebut diharapkan mampu mendorong perbankan di Indonesia menjadi lebih baik dan maju. OJK merupakan lembaga yang independen dan bebas dari campur tangan pihak lain, yang mempunyai fungsi, tugas, dan wewenang pengaturan, pengawasan, pemeriksaan, dan penyidikan terhadap Lembaga Jasa Keuangan seperti sektor Perbankan, Pasar Modal, Perasuransian, Dana Pensiun, Lembaga Pembiayaan, dan Lembaga Jasa Keuangan Lainnya ${ }^{2}$

Bank menurut Undang-undang Perbankan Nomor 10 Tahun 1998 adalah badan usaha yang menghimpun dana dari masyarakat dalam bentuk simpanan dan menyalurkannya ke masyarakat dalam bentuk kredit dan atau bentuk-bentuk lainnya dalam rangka meningkatkan taraf hidup rakyat banyak. ${ }^{3}$ Sedangkan pengertian Bank Syariah menurut Undang-undang Nomor 21 Tahun 2008 adalah bank yang menjalankan operasinya berdasarkan prinsip syariah dan menurut jenisnya terdiri atas Bank Umum Syariah (BUS) dan Bank Pembiayaan Rakyat Syariah (BPRS). Adapun Bank Pembiayaan Rakyat Syariah adalah bank syariah yang dalam kegiatannya tidak memberikan jasa dalam lalu lintas pembayaran. ${ }^{4}$

Bank dikenal sebagai lembaga yang berperan sebagai perantara keuangan (financial intermediary), yaitu perantara antara pihak yang memiliki kelebihan dana dengan pihak yang membutuhkan dana. Oleh karena itu bank harus dapat menjaga kepercayaan masyarakat dengan meningkatkan kinerja keuangan untuk mencapai tingkat profitabilitas yang tinggi. Bank harus menjaga kinerja keuangan dengan

\footnotetext{
${ }^{2}$ Undang-undang Nomor 21 tahun 2011 tentang Otoritas Jasa Keuangan (OJK).

${ }^{3}$ Undang-undang Republik Indonesia Nomor 10 Tahun 1998 Tentang Perubahan Atas Undang-undang Nomor 7 Tahun 1992 Tentang Perbankan. Syariah.

${ }^{4}$ Undang-undang Republik IndonesiaNomor 21 Tahun 2008 Tentang Perbankan
} 
baik. Karena mayoritas dana yang dikelola bank adalah dana masyarakat, sehingga bank bertanggung jawab penuh atas dana tersebut. Salah satu cara untuk menilai kinerja perbankan adalah dengan mengetahui seberapa besar kemampuan lembaga tersebut dalam menghasilkan laba. ${ }^{5}$ Laba merupakan indikator dari kinerja suatu perbankan yang menunjukkan posisi kompetitif sebuah bank di pasar perbankan serta kualitas manajemennya. ${ }^{6}$ Dan merupakan indikator kinerja terbaik bagi sebuah bank baik di masa lalu maupun masa depan. ${ }^{7}$

Return on Assets (ROA) digunakan untuk mengukur kemampuan bank dalam menghasilkan laba pada masa lalu dan dapat untuk memproyeksikan laba pada masa yang akan datang. ${ }^{8}$ ROA digunakan untuk menilai kinerja bank syariah dalam menghasilkan laba, berdasarkan aset yang berasal dari dana simpanan masyarakat. Sehingga ROA mencerminkan tingkat kepercayaan masyarakat dan sebagai tolak ukur tingkat kesehatan serta baik-buruknya manajemen bank syariah.Semakin besar ROA, maka semakin besar pula tingkat keuntungan yang dicapai dan semakin baik posisi bank dalam penggunaan aset.

ROA sangat dipengaruhi oleh semua atau sebagian rasio-rasio keuangan, ${ }^{9}$ meliputi Capital Adequacy Ratio (CAR), Non Performing Finance (NPF) dan Operational Expenses To Operational Revenue(OEOR/ BOPO), Financing To Deposit Ratio (FDR). Kondisi perbankan juga dipengaruhi oleh pengaruh makroekonomi. ${ }^{10}$ Menurut Sukirno, indikator makroekonomi meliputi pendapatan nasional, pengangguran, in-

\footnotetext{
${ }^{5}$ Al-Jufri, Fahmi Oemar, Zaharman, “Pengaruh Tingkat Kesehatan Keuangan Terhadap Penyaluran Kredit Pada PT. BPR Cempaka Mitra Nagori Kuansing di Taluk Kuatan", (Jurnal: Jurnal Ilmiah Ekonomi dan Bisnis, vol. 12, No. 2, 2015), 148.

${ }^{6}$ Hennie Van Greuning dan Zamir Iqbal, Risk Analisis For Islamic Bank (Jakarta: Salemba Empat, 2011), 99.

${ }^{7}$ Ibid, 112.

${ }^{8}$ Mamduh M. Hanafi dan Abdur Halim, Analisis Laporan Keuangan (Yogyakarta: UPP STIM YKPN, 2014), 157.

${ }^{9}$ Greuning dan Iqbal, Risk Analisis For Islamic Bank, 112.

${ }^{10}$ Tulus T.H Tambunan, Perekonomian Indonesia Kajian Teoritis dan Analisis Empiris (Bogor: Ghalia Indonesia, 2012), 86.
} 
flasi, neraca perdagangan, neraca pembayaran dan kurs. ${ }^{11} \mathrm{Hal}$ tersebut sesuai dengan Surat Edaran Bank Indonesia No.9/29/DPbS/2007 dan Peraturan Bank Indonesia No.9/17/PBI/2007.12 Penelitian ini dilakukan untuk menguji pengaruh CAR, BOPO dan Inflasi terhadap ROA. Pemilihan indikator tersebut didasarkan atas teori dan penelitian terdahulu yang dilakukan olehSahara, dan Rizal. ${ }^{13}$

Sebagian besar bank yang ada di Indonesia masih mengandalkan aktivitas pembiayaan sebagai pemasukan utama dalam membiayai operasionalnya untuk memperoleh laba. Pada umumnya di negara berkembang, seperti Indonesia sumber pembiayaan dalam bidang usaha masih didominasi oleh penyaluran pembiayaan perbankan yang diharapkan dapat mendorong pertumbuhan ekonomi. Pembiayaan merupakan aktivitas utama dalam menghasilkan keuntungan, tetapi juga memiliki risiko yang sangat besar. Oleh karena itu pembiayaan harus dikawal dengan manajemen risiko yang ketat. ${ }^{14}$

Jumlah Bank Syariah di Indonesia dari tahun ketahun mengalami pertumbuhan. Berdasarkan data Statistik Perbankan Syariah per September 2018, saat ini menunjukkan ada 14 BUS, 1.862 kantor, dengan total aset 306.121. Sedangkan berdasarkan data Statistik Perbankan Syariah per Januari 2015, ada 12 BUS, 1.990 kantor, dengan total aset 213.423. Dari data tersebut menunjukkan bahwa, secara umum dari tahun 2015 sampai 2018 BUSdi Indonesia mengalami pertumbuhan.

${ }^{11}$ Sadono sukirno, Makroekonomi Teori Pengantar (Jakarta: PT. Raja Grafindo, 2011), 17.

12 SEBI Nomor.9/29/DPbS/2007 Tentang Sistem Penilaian Tingkat Kesehatan BankPerkreditan Rakyat Berdasarkan Prinsip Syariah dan Peraturan Bank Indonesia(PBI) Nomor. 9/17/PBI/2007 Tentang Sistem Penilaian Tingkat Kesehatan Bank Perkreditan Rakyat Berdasarkan Prinsip Syariah.

${ }^{13}$ Ayu Yunita Sahara, "Analisis Pengaruh Inflasi, Suku Bunga Bi Dan Produk Domestik Bruto Terhadap Return On Asset Bank Syariah di Indonesia" (Jurnal Ilmu Manajemen Vol. 1, No. 1, 2013). Fitra Rizal, "Pengaruh Capital Adequacy Ratio, Non Performing Finance dan Operational Expenses to Operational RevenueTerhadap Return on Assets Bank Pembiayaan Rakyat Syariah di Indonesia Periode 2012-2015" ( Jurnal Muslilm Heritage, Pascasarjana IAIN Ponorogo, 2017).

${ }^{14}$ Irman Firmansyah,"Determinant Of Non Performing Loan: The Case Of Islamic Bank In Indonesia"(Buletin Ekonomi Moneter dan Perbankan, Bank Indonesia, Vol.17, No.2, 2014), 242. 
Yang lebih menarik adalah Profitabilitas yang diperoleh Bank Umum Syariah dari tahun ketahun juga mengalami peningkatan, dari 0, 49 persen pada Januari 2015, naik menjadi 1,41 persen pada September 2018. ${ }^{15}$ Perhatikan tabel berikut ini :

Tabel 1.1

Data CAR, BOPO dan Inflasi BUS 2015-2018

\begin{tabular}{|c|c|c|c|c|}
\hline TAHUN & CAR (\%) & $\begin{array}{c}\text { BOPO } \\
(\%)\end{array}$ & $\begin{array}{c}\text { Inflasi } \\
(\%)\end{array}$ & ROA (\%) \\
\hline 2015 & 15,02 & 97,01 & 3,35 & 0,49 \\
\hline 2016 & 15,63 & 96,23 & 3,02 & 0,63 \\
\hline 2017 & 17,91 & 94,91 & 3,61 & 0,63 \\
\hline September 2018 & 21,25 & 88,01 & 2,88 & 1,41 \\
\hline
\end{tabular}

Sumber: http://www.ojk.go.id dan http://www.bi.go.id, data diolah.

Capital Adequacy Ratio (CAR) adalah rasio kecukupan modal yang menunjukkan kemampuan bank dalam mempertahankan kecukupan modal serta kemampuan manajemen bank dalam mengontrol risikorisiko yang mungkin timbul dari operasional perbankan. ${ }^{16} \mathrm{CAR}$ penting bagi perbankan karena merupakan salah satu faktor untuk menilai kinerja perbankan tersebut. ${ }^{17}$ A pabila CAR naik maka rasio kecukupan modal yang digunakan menjadi lebih baik, sehingga meningkatkan kinerja dan operasional bank serta kepercayaan masyarakat terhadap perbankan tersebut, dan pada akhirnya akanmeningkatkan profitabilitas. Hal ini menunjukkan bahwa CAR mempunyai hubungan positif terhadap ROA.Hal tersebut sesuai dengan hasil penelitian Stiawan dan Chistiano dkk, yang menyatakan bahwa CAR berpengaruh positif dan

${ }^{15}$ Statistik Perbankan Syariah, 2015-2018, http://www.ojk.go.id dan http://www. bi.go.id.

${ }^{16}$ Mundrajad Kuncoro dan Suhardjono, Manajemen Perbankan (Yogyakarta: BPFE UGM, 2002), 256.

${ }^{17}$ Hennie Van Greuning dan Zamir Iqbal, Risk Analisis For Islamic Bank, 211. 
singnifikan terhadap ROA. ${ }^{18}$ Akantetapi dalam penelitian Krisnawati, menyatakan bahwa CAR tidak berpengaruh terhadap ROA. ${ }^{19}$

BOPO atau yang disebut denganOperational Expenses To Operational Revenue (OEOR) adalah rasio yang digunakan untuk mengukur kemampuan manajemen bank dalam mengendalikan biaya operational yang dikeluarkan untuk memperoleh pendapatan operasional. ${ }^{20} \mathrm{BOPO}$ digunakan untuk mengukur tingkat efisiensi dan kemampuan bank dalam melakukan kegiatan operasionalnya dalam memperoleh laba. Perlu diketahui bahwa risiko operasional tersebut merupakan risiko yang paling sering dihadapi perbankan syariah. ${ }^{21}$ Semakin besar tingkat BOPO suatu bank maka kinerja dan operasional bank akan menurun karena besarnya beban yang diterima. Dan pada akhirnya hal tersebut akan menurunkan tingkat profitabilitas bank sehingga BOPO berpengaruh negatif terhadap ROA. Hal tersebut sesuai dengan penelitian Krisnawati dan Christiano, yang menyatakan bahwa OEOR berpengaruh negatif dan signifikan terhadap ROA.22Akantetapi dalam penelitian yang dilakukan oleh Astutik,menunjukkan bahwa BOPO tidak berpengaruh terhadap ROA. ${ }^{23}$

Inflasi merupakan kenaikan harga barang dan jasa secara umum selama satu periode tertentu. ${ }^{24}$ Tingkat inflasi yang tinggi akan menyebabkan naiknya konsumsi, sehingga akan mempengaruhi pola

${ }^{18}$ Penelitian AdiStiawan dan Mario Christiano menyatakan bahwa CAR berpengaruh positif dan signifikan terhadap ROA.

${ }^{19}$ Penelitian Lina Krisnawati menyatakan bahwa CAR tidak berpengaruh terhadap ROA.

${ }^{20}$ Mario Charistiano, Parengkuan Tomy Dan Ivonne Saerang, "Analisis Terhadap Rasio-Rasio Keuangan Untuk Mengukur Profitabilitas Pada Bank -Bank Swasta Yang Go Public Di Bursa Efek Indonesia" (Jurnal: EMBA Vol. 2, No. 4, 2014).

${ }^{21}$ Greuning dan Iqbal, Risk Analisis For Islamic Bank, 167.

${ }^{22}$ Penelitian Krisnawati dan Christiano dkk, menyatakan bahwa BOPO berpengaruh negatif dan signifikan terhadap ROA.

${ }^{23}$ Puji Astutik, "Pengaruh Tingkat Kesehatan Bank Menurut Risk Based Bank Rating Terhadap Kinerja Keuangan (Studi Pada Bank Umum Syariah di Indonesia",(Jurnal: Fakultas Ekonomi Dan Bisnis Universitas Brawijaya).

${ }^{24}$ Adiwarman A. Karim. Ekonomi Makro Islam (Jakarta: PT Raja Grafindo Persada, 2010), 135. 
saving dan pembiayaan pada masyarakat. Perubahan tersebut akan berdampak pada kegiatan operasional bank syariah. Jumlah dana masyarakat yang dihimpun akan semakin berkurang sehingga dapat mempengaruhi kinerja bank syariah dalam memperoleh keuntungan.Salah satu akibat inflasi adalah menurunkan taraf kemakmuran masyarakat. ${ }^{25}$ Ketika terjadi inflasi maka suku bunga akan naik dan mengakibatkan masyarakat enggan meminjam pada pihak bank. Selain itu perusahaan sektor riil juga enggan untuk menambah modal untuk membiayai produksinya dan akan berdampak pada turunnya profitabilitas bank. Hasil penelitian Sahara, menyatakan bahwa inflasi perpengaruh positif terhadap $\mathrm{ROA}^{26}$.Akantetapi dalam penelitian yang dilakukan oleh Rizal, Inflasi tidak berpengaruh terhadap ROA. ${ }^{27}$

Berdasarkan penjelasan di atas, maka penelitian ini berjudul " Faktor Penentu Profitabilitas Bank Umum Syariah di Indonesia: Pasca Peralihan TugasPengawasan Perbankan dari BI ke OJK". Penelitian ini menguji Capital Adequacy Ratio, Operational Expenses to Operational Revenue dan Inflasi terhadap Return on Assets Bank Umum Syariahdi Indonesia Periode 2015-2018.

\section{BANK UMUM SYARIAH}

Bank adalah badan usaha yang menghimpun dana dari masyarakat dalam bentuk simpanan dan menyalurkannya ke masyarakat dalam bentuk kredit dan atau bentuk-bentuk lainnya dalam rangka meningkatkan taraf hidup rakyat banyak. ${ }^{28}$ Adapun pengertian bank syariah adalah bank yang beroperasi berdasarkan prinsip syariah dan menurut jenisnya terdiri Bank Umum Syariah dan Pembiayaan Rakyat

${ }^{25}$ Sadono sukirno, Makroekonomi Teori Pengantar (Jakarta: PT. Raja Grafindo, 2011), 15

${ }^{26}$ Ayu Yunita Sahara, "Analisis Pengaruh Inflasi, Suku Bunga Bi Dan Produk Domestik Bruto Terhadap Return On Asset Bank Syariah di Indonesia" (Jurnal Ilmu Manajemen Vol. 1, No. 1, 2013).

${ }^{27}$ Fitra Rizal, "Analisis Pengaruh Makroekonomi Terhadap Profitabilitas Perbankan Syariah Di Indonesia Periode 2005-2013" (Skripsi, Universitas Muhammadiyah Yogyakarta, 2014).

${ }^{28}$ Ismail,Manajemen Perbankan (Jakarta : Kencana Prenada Media Group, 2010) 3. 
Syariah. ${ }^{29}$ Bank syariah beroperasi mengikuti ketentuan-ketentuan syariah Islam, khususnya yang menyangkut tata cara bermuamalat misalnya dengan menjauhi praktik yang mengandung unsur riba dan melakukan kegiatan investasi atas dasar bagi hasil pembiayaan.

\section{PROFITABILITAS}

Profitabilitas mengukur kemampuan perusahaan dalam menghasilkan keuntungan pada tingkat penjualan, asset dan modal saham. Profitabilitas mengukur kemampuan perusahaan dalam menghasilkan laba bersih berdasarkan tingkat aset yang tertentu. Rasio yang tinggi menunjukkan efisiensi manajemen asset yang baik. ${ }^{30}$ Profitabilitas menunjukkan efektivitas sebuah perusahaan dalam menciptakan laba. Laba pada dasarnya menunjukkan seberapa baik perusahaan tersebut dalam membuat keputusan investasi dan pembiayaan. Dan tujuan utama dari operasional bisnis perusahaan jasa adalah untuk menghasikan laba.

Rasio profitabilitas merupakan rasio untuk mengukur kemampuan perusahaan dalam menghasilkan keuntungan pada tingkat penjualan, asset dan modal saham. Dalam pembahasan profitabilitas, ada tiga rasio yang sering dibicarakan yaitu profit margin, return on asset (ROA) dan return on equity (ROE). Indikator profitabilitas yang sering dipakai dalam dunia perbankan adalah Return On Asset (ROA) dan Return On Equity (ROE). Return On Asset (ROA). ${ }^{31}$ Return On Assets (ROA) mengukur kemampuan perusahaan dalam menghasilkan laba pada masa lalu yang dapat dijadikan proyeksi laba tahun yang akan datang. ROA mengukur kemampuan perusahaan dalam menghasilkan laba dengan menggunakan total aset yang dipunyai perusahaan setelah disesuaikan dengan biaya-biaya untuk mendanai aset tersebut. ${ }^{32}$ ROA menunjukkan kemampuan bank dalam menghasilkan laba

${ }^{29}$ Dewi Nurul Musjtaridan Fadia Fitrianti, Hukum Perbankan Syariah dan Takaful (Dalam Teori dan Praktek)(Yogyakarta: Lab. Hukum UMY. 2010), 53.

${ }^{30}$ Hanafi dan Halim, Analisis Laporan Keuangan, 81-82.

${ }^{31}$ Ibid.

${ }^{32} \mathrm{Ibid}, 157$. 
dari pengelolaan asset yang dimiliki. ROA digunakan untuk mengukur profitabilitas bank dengan aset yang dananya sebagian besar dari dana simpanan masyarakat. Semakin besar ROA suatu bank, maka semakin besar pula tingkat keuntungan yang dicapai bank tersebut. Dalam rangakan menilai kesehatan Bank, BI akan memberikan nilai maksimal 100 (sehat) apabila ROA lebih dari 1,5 Persen.

Dapat dipahami semakin besar ROA suatu bank, maka semakin besar pula tingkat keuntungan yang dicapai dan semakin baik pula posisi bank tersebut dari sisi penggelolaan aset. Dan sebaliknya jika semakin kecil ROA, maka mengindikasikan menurunnya laba karena bank tidak mampu mengelola aset dengan benar. Perlu diketahui bahwa semakin besar ROA yang diperoleh maka semakin efisien bank dalam mengelola aset (aktiva), sehingga akan memperbesar laba. Dan pada akhirnya laba yang besar akan menarik nasabah untuk bertransaksi di bank tersebut karena bank tersebut memiliki tingkat kembalian yang tinggi. ${ }^{33}$

\section{CAPITAL ADEQUACY RATIO}

$C A R$ atau disebut rasio kecakupan modal adalah rasio yang menunjukkan kemampuan bank dalam menyediakan dana untuk keperluan pengembangan usaha dan pelindung risiko kerugian yang diakibatkan oleh kegiatan operasional. Semakin tinggi CAR semakin baik kondisi sebuah bank. ${ }^{34}$ Secara umum CAR dapat dipahami sebagai rasio kecukupan modal yang digunakan dalam membiayai operasional perbankan dalam memperoleh laba dan sebagi pelindung ketika terjadi kerugian dan goncangan dari kegiatan operasional perbankan tersebut.Standar minimum dalam kecukupan modal bagi bank syariah adalah 8 persen. ${ }^{35}$ 345.

${ }^{33}$ Khaerul Umam, Manajemen Perbankan Syariah (Bandung: Pustaka Setia, 2013),

${ }^{34}$ Van Greuning dan Zamir Iqbal, Risk Analisis For Islamic Bank, 113.

${ }^{35} \mathrm{Ibid}, 118$. 


\section{RASIO ANTARA BIAYA OPERASIONAL TERHADAP PENDAPA- TAN OPERASIONAL (BOPO)}

BOPO atau yang disebut denganOperational Expenses To Operational Revenue (OEOR) adalah rasio yang digunakan untuk mengukur kemampuan manajemen bank dalam mengendalikan biaya operational yang dikeluarkan untuk memperoleh pendapatan operasional. ${ }^{36}$ Secara singkat BOPO digunakan untuk mengukur tingkat efisiensi dan kemampuan bank dalam melakukan kegiatan operasionalnya dalam memperoleh laba. Perlu diketahui bahwa risiko operasional tersebut merupakan risiko yang paling sering dihadapi perbankan syariah. ${ }^{37}$ Semakin besar tingkat BOPO suatu bank maka kinerja dan opersional bank akan menurun karena besarnya beban yang diterima.

BOPO diukur dari perbandingan antara beban operasional terhadap pendapatan operasioanal. Beban operasional merupakan beban biaya yang dikeluarkan oleh bank dalam rangka menjalankan aktivitas usaha pokoknya. Adapun beberapa indikator dalam biaya operasional diantaranya adalah biaya tenaga kerja, biaya pemasaran, biaya terkait karakteristik dan kompleksitas bisnis, biaya terkait sumberdaya manusia, biaya terkait teknologi informasi dan infrasuktur pendukung dan biaya operasional lainnya. ${ }^{38}$ Menurut ketentuan BI besarnya BOPO yang normal berkisar antara $94-96$ persen. ${ }^{39}$

\section{INFLASI}

Inflasi merupakan kenaikan tingkat harga secara umum dari barang atau komoditas dan jasa selama satu periode tertentu. Inflasi dapat dianggap sebagai fenomena moneter karena terjadinya penurunan nilai unit perhitungan moneter terhadap suatu komoditas. Sedangkan

${ }^{36}$ Mario Charistiano, "Parengkuan Tomy Dan Ivonne Saerang, "Analisis Terhadap Rasio-Rasio Keuangan Untuk Mengukur Profitabilitas Pada Bank -Bank Swasta Yang Go Public Di Bursa Efek Indonesia" (Jurnal: EMBA Vol. 2, No. 4, 2014).

${ }^{37}$ Greuning dan Iqbal, Risk Analisis For Islamic Bank, 167.

38 SEOJK Nomor 10/SEOJK.03/2014 Tentang Penilaian Tingkat Kesehatan Bank Umum Syariah Dan Unit Usaha Syariah

${ }^{39}$ Lukman Dendawijaya. Manajemen Perbankan (Jakarta: Ghalia Indonesia, 2005) 
Inflasi menurut para ekonom modern adalah kenaikan yang menyeluruh dari jumlah uang yang harus dibayarkan terhadap barang atau komoditas dan jasa. ${ }^{40}$ Kenaikan inflasi dapat diukur dengan indeks harga. Beberapa indeks harga yang sering digunakan untuk mengukur inflasi antra lain, indeks biaya hidup, indeks harga perdagangan besar, gross national product deflator. ${ }^{41}$ Indeks harga yang selalu digunakan adalah indeks harga konsumen (IHK).Adapun menuut Budiono, untuk mencapai kestabilan pembagunan inflasi harus berada pada level 3-4 persen.

\section{METODOLOGI PENELITIAN}

Jenis penelitan yang digunakan dalam penelitian ini adalah metode penelitian kuantitatif karena data yang digunakan berupa angkaangka yang dianalisis menggunakan statistik, yang bertujuan untuk mengetahui pengaruh antar variabel dalam populasi ${ }^{42}$ dengan bantuan alat analisis SPSS 21. Variabel harus didefinisikan secara operasional agar lebih mudah dicari hubungannya antara satu variabel dengan lainnya dan pengukurannya. ${ }^{43}$ Penelitian ini menggunakan 2 variabel, yaitu variabel terikat/dependen (ROA) dan variabel bebas/ independen (CAR, BOPO dan Inflasi).

Sumber data yang digunakan berupa dokumen Laporan Statistik Perbankan Syariah yang dipublikasikan oleh Bank Indonesia dan Otoritas Jasa Keungan. Jenis data yang digunakan dalam penelitian ini adalah data sekunder. Periode penelitian dari Januari 2015-September 2018. Teknik pengumpulan data yang digunakan adalah dokumentasi. Dokumentasi merupakan metode pengumpulan data yang bersumber

${ }^{40}$ Adiwarman A. Karim. Ekonomi Makro Islam (Jakarta: PT Raja Grafindo Persada, 2010), 135.

${ }^{41}$ Nopirin. Ekonomi Moneter (Yogyakarta: BPFE Yogyakarta, 2009), 25.

${ }^{42}$ Sugiono, Metode Penelitian Kuantitatif, Kualitatif dan $R \mathcal{E} D$ (Bandung: Alfabeta, 2010), 7.

${ }^{43}$ Jonathan Sarwono, Metode Penelitian Kuantitatif dan Kualitatif (Yogyakarta: Graha Ilmu, 2006), 67. 
dari benda-benda yang tertulis. ${ }^{44}$ Data tersebut bersumber dari dokumen laporan statistik perbankan syariah yang dipublikasikan oleh Bank Indonesia dan Ototitas Jasa Keungan lewat situs, www.bi.go.id dan www.ojk.go.id.

\section{ANALISIS DESKRIPTIF}

Statistik deskriptif berhubungan dengan pengambaran sebuah data dan bagaimana karakteristik data tersebut. ${ }^{45}$ Penggunaan statistik deskriptif dalam penelitian ini memberikan gambaran atau deskripsi suatu data yang dilihat dari maksimum, minimum, mean dan standardeviasi, ${ }^{46} \mathrm{Di}$ bawah ini adalah deskripsi data yang digunakan dalam penelitian :

\section{Tabel 1.2}

\section{Hasil Deskripsi Data}

\begin{tabular}{|c|c|c|c|c|c|}
\hline & $\mathrm{N}$ & Minimum & Maximum & Mean & $\begin{array}{c}\text { Standar De- } \\
\text { viasi }\end{array}$ \\
ROA & 45 & 0,16 & 1,41 & 0,8189 & 0,31016 \\
CAR & 45 & 14,09 & 21,25 & 16,3167 & 1,88532 \\
BOPO & 45 & 88,01 & 99,04 & 94,1649 & 2,90994 \\
INFLASI & 45 & 2,79 & 7,26 & 4,3004 & 1,44899 \\
\hline
\end{tabular}

Sumber: Data Output SPSS (data diolah)

${ }^{44}$ Mario Christiano, Parengkuan Tommy dan Ivonne Saerang, "Analisis Terhadap Rasio-Rasio Keuangan Untuk Mengukur Profitabilitas Pada BankBank Swasta Yang Go Public Di Bursa Efek Indonesia", 821.

${ }^{45}$ Rahmawati, Fajarwati dan Fauziyah, Statistika Teori dan Praktek, 2Statistika Teori dan Praktek (Yogyakarta: Prodi Manajemen Universitas Muhammadiyah Yogyakarta, 2014), 40.

${ }^{46}$ Imam Ghazali, Aplikasi Analisis Multivariate Dengan Program IBM SPSS 21 (Semarang: Badan Penerbit Universitas Diponegoro, 2013), 19. 


\section{UJI ASUMSI KLASIK}

\section{Uji Multikolinearitas}

Uji multikolinearitas bertujuan untuk menguji apakah model regresi ditemukan adanya korelasi antara variabel bebas (independen). Model regresi yang baik seharusnya tidak terjadi korelasi di antara variabel independen. ${ }^{47}$ Perhatikan tabel dibawah ini :

Tabel 1.3

Hasil Uji Multikolinearitas Coefficients ${ }^{a}$

\begin{tabular}{|c|c|c|}
\hline \multirow{2}{*}{ Model } & \multicolumn{2}{|c|}{ Collinearity Statistics } \\
\cline { 2 - 3 } & Tolerance & VIF \\
\hline 1 (Constant) & & \\
CAR & 0,256 & 3,907 \\
BOPO & 0,316 & 3,162 \\
INFLASI & 0,664 & 1,506 \\
\hline
\end{tabular}

Dependent Variable: ROA

Sumber: Data Output SPSS (diolah)

Dari tabel 1.3 bisa dilihat bahwa nilai tolerance masing-masing variabel independen tidak ada yang lebih kecil dari 0,10. Begitu juga nila VIF masing-masing variabel independen tidak ada yang lebih besar dari 10. Maka dapat dinyatakan bahwa tidak terjadi multikolinearitas dalam model yang dipakai.

\section{Uji Autokorelasi}

Uji Autokorelasi bertujuan untuk menguji apakah dalam model regresi linear ada korelasi antara kesalahan pengganggu pada periode $t$ dengan kesalahan pengganggu pada periode t-1 (sebelumnya). Jika terjadi korelasi maka dinamakan ada problem autokorelasi. ${ }^{48}$ Perhatikan tabel dibawah ini :

\footnotetext{
47 Ibid., 105.

${ }^{48}$ Ibid, 110.
} 
Tabel 1.4

Hasil Uji Autokorelasi Model Summary ${ }^{b}$

\begin{tabular}{|c|c|c|c|c|c|}
\hline Model & R & R Square & $\begin{array}{c}\text { Adjusted } \\
\text { R Square }\end{array}$ & $\begin{array}{c}\text { Std. Error of } \\
\text { The Estimate }\end{array}$ & $\begin{array}{c}\text { Durbin- } \\
\text { Watson }\end{array}$ \\
\hline 1 & $0,958^{\mathrm{a}}$ & 0,918 & 0,912 & 0,09196 & 1,354 \\
\hline
\end{tabular}

Predictors: (Constant), INFLASI, BOPO, CAR,

Dependent Variable: ROA

Sumber: Data Output SPSS (data diolah)

Berdasarkan dari output pada tabel 1.4 didapat nilai DurbinWatson yang dihasilkan dari model regresi adalah 1,354, pada nilai DW ini diatara -2 sampai dengan 2, maka dapat disimpulkan bahwa pada uji ini tidak terdapat auotokorelasi. ${ }^{49}$

\section{Uji Heteroskedastisitas}

Uji Heteroskedastisitas bertujuan untuk menguji apakah dalam model regresi terjadi ketidak samaan varians dari residual satu pengamatan ke pengamatan yang lain..$^{50}$ Model regresi yang baik adalah yang Homokedastisitas, atau tidak terjadi Heterokedastisitas.Perhatikan grafik dibawah ini :

${ }^{49}$ Hermanto dan Endah.Saptuningsih. Electronic Data Processing SPSS 10 dan Eviews 3.0(Yogyakarta: UPFe UMY, 2002), 59

${ }^{50}$ ImamGhazali, Aplikasi Analisis Multivariate dengan Program IBM SPSS 21, 139. 




Sumber: Data Output SPSS (data diolah)

Dari grafik Scatterplot diatas terlihat bahwa titik-titik menyebar secara acak serta tersebar baik diatas maupun dibawah angka 0 pada sumbu Y. Hal ini dapat disimpulkan bahwa tidak terjadi heteroskedasitas.

\section{Uji Normalitas}

Uji Normalitas bertujuan untuk menguji apakah dalam model regresi variabel pengganggu atau residual memiliki distribusi normal. Model regresi yang baik memiliki distribusi data normal atau mendekati normal. ${ }^{51}$ perhatikan tabel Tabel 1.5.

\footnotetext{
${ }^{51}$ Ibid, 160.
} 
Tabel 1.5

Hasil Uji Normalitas

One-Sample Kolmogrov-Smirnov Test

\begin{tabular}{|c|c|}
\hline & $\begin{array}{c}\text { Unstandardizer } \\
\text { Residual }\end{array}$ \\
\hline N & 45 \\
Normal Parameters ${ }^{\text {a.b }}$ Mean & 0,0000000 \\
Std.Deviation & 0,08876868 \\
Absolute & 0,131 \\
Most Extreme Differences Positif & 0,131 \\
Negative & $-0,084$ \\
Kolmogrov-Smirnov Z & 0,875 \\
Asymp. Sig. (2-tailed) &, 427 \\
\hline
\end{tabular}

Test distribution is Normal

Calculatet from data

Sumber: Data Output SPSS (data diolah)

Uji Normalitas menunjukkan hasil yang tidak signifikan. Besarnya nilai Kolmogrov-Smirnov adalah 0,875 dan signifikansinya 0,427. Berdasarkan hasil tersebut dapat disimpulkan bahwa data berdistribusi normal karena tingkat signifikannsinya lebih besar dari 0,05.

\section{UJI KOEFISIEN DETERMINASI}

Uji koefisien determinasi $\left(R^{2}\right)$ untuk mengukur seberapa jauh kemampuan model dalam menerangkan variasi variabel dependen yaitu ROA.Dari hasil output pada tabel 1.6. menunjukan nilai koefisien determinasi (Adjusted $\mathrm{R}^{2}$ ) sebesar 0,912 yang berarti 91,2 persen variabel dependen (ROA) dapat dijelaskan oleh variabel independen (CAR, BOPO dan Inflasi), sedangkan 8,8 persen sisanya dijelaskan oleh variabel lain diluar penelitian ini. Perhatikan tabel berikut ini: 
Tabel 1.6

Hasil Koefisien Determinasi Model Summary ${ }^{b}$

\begin{tabular}{|r|r|r|r|r|}
\hline Model & $\mathrm{R}$ & \multicolumn{1}{|c|}{$\begin{array}{c}\mathrm{R} \\
\text { Square }\end{array}$} & $\begin{array}{c}\text { Adjusted } \\
\text { R Square }\end{array}$ & $\begin{array}{c}\text { Std. Error of The } \\
\text { Estimate }\end{array}$ \\
\hline 1 & $0,958^{\mathrm{a}}$ & 0,918 & 0,912 & 1,354 \\
\hline
\end{tabular}

Predictors: (Constant), INFLASI, BOPO, CAR

a. Dependent Variable: ROA

Sumber: Data Output SPSS (data diolah)

\section{UJI SIGNIFIKANSI PARAMETER INDIVIDUAL ( UJI STATISTIK T)}

Uji statistik t pada dasarnya menunjukkan seberapa jauh pengaruh satu variabel penjelas atau independen secara individual dalam menerangkan variasi variabel dependen. Perhatikan tabel berikut ini:

Tabel 1.7

Hasil Uji Statistik $\mathbf{t}$ Coefficients ${ }^{\mathrm{a}}$

\begin{tabular}{|c|c|c|c|c|c|}
\hline \multirow{2}{*}{ Model } & \multicolumn{2}{|c|}{$\begin{array}{c}\text { Unstandardized Coef- } \\
\text { ficients }\end{array}$} & $\begin{array}{c}\text { Standard- } \\
\text { ized Coef- } \\
\text { ficients }\end{array}$ & $\mathrm{t}$ & \multirow{2}{*}{ Sig. } \\
\cline { 2 - 4 } & $\mathrm{B}$ & Std. Error & Beta & & \\
\hline 1 (Constant) & 12,054 & 1,008 & & 11,962 & 0,000 \\
CAR & $-0,025$ & 0,015 & $-0,150$ & $-1,700$ & 0,097 \\
BOPO & $-0,115$ & 0,008 & $-1,080$ & $-13,583$ & 0,000 \\
INFLASI & $-0,001$ & 0,012 & $-0,004$ & 0,080 & 0,936 \\
\hline
\end{tabular}

Dependent Variable: ROA

Sumber: Data Output SPSS (data diolah)

Berdasarkan perhitungan pada tabel 1.7 dapat disimpulkan sebagai berikut: 


\section{Pengaruh CARTerhadap ROA BUS}

Hipotesis pertama yang diajukan pada penelitian ini adalah CAR berpengaruh positif dan signifikan terhadap ROA. Berdasarkan hasil pengujian secara parsial (uji t) antara variabel CAR dengan ROA menunjukan bahwa nilai $\mathrm{t}-1,700$, koefisien regresi sebesar $-0,025$ dengan nilai signifikansi sebesar 0,097lebih besar dari 0,05 berarti CAR tidak berpengaruh terhadap ROA. Maka dapat disimpulkan dalam penelitian ini bahwa CAR tidak berpengaruh terhadap ROA, sehingga hipotesis pertama yang menyatakan CAR berpengaruh positif dan signifikan terhadap ROA tidak terbukti.

Selama periode penelitian CAR tidak berpengaruh terhadap ROA Bank Umum Syariah di Indonesia. Dari data yang diperoleh Kondisi permodalan BUS di Indonesia pada periode Januari 2015 sampai September 2018 cukup baik karena rata-rata CAR pada periode tersebut adalah 16,31 jauh diatas standar minimal CAR sebesar 8 persen. Kondisi tersebut menjelaskan bahwa BUS belummampu melakukan pembiayaan secara optimal. Selanjutnya efek dari kualitas pembiayaan dan besarnya beban operasional BUS akan berdampak pada besarnya penyisihan penghapusan aktiva produktif (PPAP). Maka dari itu rasio CAR harus ditingkatakan untuk mengantisipasi berbagai resiko yang mungkin muncul. ${ }^{52}$ Berdasarkan data yang diperoleh selama penelitian rata-rata Non Performing Financing(NPF) BUS adalah 4,47 termasuk dalam Kategori kualitas aset baik namun terdapat kelemahan yang tidak signifikan. ${ }^{53}$ Ditambah kondisi kurs rupiah yang terdepresiasi sehingga perlu adanya antisipasi resiko ataupun kelemahan yang mungkin muncul, maka CAR harus lebih dari cukup. Untuk lebih menggambarkan kondisi tersebut lihat tabel 1.8 berikut ini :

${ }^{52}$ Fitra Rizal, "Pengaruh Capital Adequacy Ratio, Non Performing Finance dan Operational Expenses to Operational RevenueTerhadap Return on Assets Bank Pembiayaan Rakyat Syariah di Indonesia Periode 2012-2015", 189

${ }^{53}$ PBI Nomor 8/21/PBI/2006 tentang Penilaian Kualitas Bank Umum Yang Melaksanakan Kegiatan Usaha Berdasarkan Prinsip Syariah. 
Tabel 1.8

Data Pergerakan CAR, NPF dan Kurs 2015- 2018

\begin{tabular}{|c|c|c|c|}
\hline TAHUN & CAR (\%) & NPF (\%) & Kurs (Rp) \\
\hline 2015 & 15,02 & 4,84 & 13.795 \\
\hline 2016 & 15,63 & 4,42 & 13.436 \\
\hline 2017 & 17,91 & 4,77 & 13.548 \\
\hline $\begin{array}{c}\text { September } \\
2018\end{array}$ & 21,25 & 3,82 & 14.934 \\
\hline
\end{tabular}

Sumber: http://www.ojk.go.id, data diolah.

\section{Pengaruh BOPO Terhadap ROA BUS}

Hipotesis kedua yang diajukan pada penelitian ini adalah BOPO berpengaruh negatif dan signifikan terhadap ROA. Berdasarkan hasil pengujian secara parsial (uji $t$ ) antara variabel BOPO dengan ROA menunjukan bahwa nilai $t-13,583$ koefisien regresi sebesar $-0,115$ dengan nilai signifikansi sebesar 0,000 lebih kecil dari 0,05 berarti BOPO berpengaruh terhadap ROA. Maka dapat disimpulkan dalam penelitian ini bahwa BOPO berpengaruh negatif dan signifikan terhadap ROA, sehingga hipotesis kedua yang menyatakan BOPO berpengaruh negatif dan signifikan terhadap ROA terbukti.

Selama periode penelitian tahun 2015 sampai 2018 BOPO cenderung mengalami fluktuasi dengan nilai rata-rata 94,31.Risiko operasional (BOPO) merupakan resiko yang paling sering dihadapi oleh perbankan. ${ }^{54}$ Tingginya beban operasional pada umumnya akan dibebankan pada pendapatan yang diperoleh dari alokasi pembiayaan. Beban yang tinggi akan mengurangi permodalan dan laba yang diperoleh. Jadi semakin besar tingkat BOPO suatu bank maka kinerja dan opersional bank akan menurun karena besarnya beban yang diterima. Dan pada akhirnya akan menurunkan tingkat profitabilitas, sehingga BOPO berpengaruh negatif dan signifikan terhadap ROA.

${ }^{54}$ Hennie Van Greuning dan Zamir Iqbal, Risk Analisis For Islamic Bank, 167. 


\section{Pengaruh InflasiTerhadap ROA BUS}

Hipotesis ketiga yang diajukan pada penelitian ini adalah inflasi berpengaruh negatif dan signifikan terhadap ROA. Berdasarkan hasil pengujian secara parsial (uji $t$ ) antara variabel inflasi dengan ROA menunjukan bahwa nilai t 0,080, koefisien regresi sebesar -0,001 dengan nilai signifikansi sebesar 0,936 lebih besar dari 0,05 berarti inflasi tidak berpengaruh terhadap ROA. Maka dapat disimpulkan dalam penelitian ini bahwa inflasi tidak berpengaruh terhadap ROA, sehingga hipotesis pertama yang menyatakan inflasi berpengaruh negatif dan signifikan terhadap ROA tidak terbukti.

Rata-rata tingkat inflasi dalam penelitian ini sebesar4,30 persen sehingga masuk dalam golongan inflasi yang rendah. Laju inflasi yang rendah atau kurang dari 10 persen dikategorikan dalam inflasi merayap. ${ }^{55}$ Laju inflasi yang rendah tidak memicu gejala-gejala negatif dalam perekonomian sehingga tidak berakibat negatif terhadap profitabitas BUS. Pergerakan inflasi yang rendah tidak memicu kepanikan pemilik modal dan deposan untuk melakukan penarikan dana besar-besaran dari bank sehingga tingkat likuiditas dan profitabilitas BUS tetap terkendali.

Jikaterjadi kenaikan tingkatinflasi, maka gaji atau upah pekerja juga akan naik. ${ }^{56}$ Inflasi dalam jangka pendek akan menurunkan upah riil para pekerja, akan tetapi dalam jangka panjang upah pekerja akan mengalami kenaikan karena menyesuaikan tingkat inflasi. Hal ini terbukti selama periode penelitan inflasi mengalami fluktuasi dari tahun 2015 sampai 2018 sedangkan tingkat PDB cenderung mengalami peningkatan pada setiap tahunnya. Pertumbuhan ekonomi Indonesiayang semula sebesar 5,04 persen di tahun 2015 mengalami pertumbuhan sebesar 5, 27 persen di triwulan II-2018. ${ }^{57}$ Ketika inflasi meningkat dan diikuti dengan penyesuaian tingkat pendapatan, maka

\footnotetext{
${ }^{55}$ Nopirin. Ekonomi Moneter (Yogyakarta: BPFE Yogyakarta, 2009), 27.

${ }^{56}$ Ibid., 35.

${ }^{57}$ www.bps.go.id
} 
pola seving masyarakat tidak terganggu.Inflasi tidak berpengaruh negatif bagi masyarakat yang berpendapatan tinggi.

\section{UJI SIGNIFIKANSI SIMULTAN (UJI STATISTIK F)}

Uji statistik F menunjukan bahwa apakah semua variabel independen yang dimaksudkan dalam model regresi mempunyai pengaruh secara simultan terhadap variabel dependen. Perhatikan tabel berikut ini:

Tabel 1.9

Hasil Uji Statistik F ANOVA ${ }^{a}$

\begin{tabular}{|c|c|c|c|c|c|}
\hline Model & $\begin{array}{c}\text { Sum of } \\
\text { Squares }\end{array}$ & Df & $\begin{array}{c}\text { Mean } \\
\text { Square }\end{array}$ & F & Sig. \\
\hline 1 Regres- & 3,886 & 3 & 1,295 & 153,174 & $0,000^{\mathrm{b}}$ \\
sion & 0,347 & 41 & 0,008 & & \\
Residual & 4,233 & 44 & & & \\
Total & & & & & \\
\hline
\end{tabular}

Dependent Variable : ROA

Predictors : (Constant), INFLALSI, BOPO, CAR

Sumber: Data Output SPSS (data diolah)

\section{Pengaruh CAR, BOPO dan Inflasi secara simultanterhadap ROA BUS}

Dari hasil analisis regresi dapat diketahui bahwa secara simultan variabel CAR, BOPO dan inflasimemiliki pengaruh yang signifikan terhadap variabel dependen. Hal ini dapat dibuktikan dari nilai $\mathrm{F}$ hitung sebesar 153,174 dengan nilai signifikansi sebesar 0,000. Karena nilai signifikansi jauh lebih kecil dari 0,05 maka dapat disimpulkan bahwa CAR, BOPO dan inflasi secara bersama-sama berpengaruh dan signifikan terhadap ROA. Hal tersebut dapat terjadi karena profitabilitas perbankan dapat dipengaruhi oleh semua atau sebagian rasio-rasio keuangan yang bersifat internal dan faktor-faktor makro ekonomi yang bersifat eksternal. 


\section{PENUTUP}

Setelah melakukan olah data dan pembahasan, terdapat beberapa kesimpulansebagai berikut, selama periode penelitian menunjukkan bahwa secara parsial CAR dan Inflasi tidak berpengaruh terhadap ROA Bank Umum Syariahdi Indonesia.Hanya BOPO yang berpengaruh negatif dan signifikan terhadap ROABank Umum Syariahdi Indonesia. Namun secara simultan CAR, BOPO dan Inflasiberpengaruh dan signifikan terhadap ROA Bank Umum Syariah di Indonesia.Hal ini menunjukkan bahwa BOPO merupakan risiko yang paling berbahaya dan risiko yang sering dihadapi oleh perbankan, maka risiko tersebut harus diantisipasi dengan baik. Semakin besar tingkat BOPO suatu bank maka kinerja dan opersional bank akan menurun karena besarnya beban yang diterima. Dan pada akhirnya akan menurunkan tingkat profitabilitas, sehingga BOPO berpengaruh negatif dan signifikan terhadap ROA.

\section{DAFTAR RUJUKAN}

Al-Jufri. Oemar, Fahmi. Zaharman. "Pengaruh Tingkat Kesehatan Keuangan Terhadap Penyaluran Kredit Pada PT. BPR Cempaka Mitra Nagori Kuansing di Taluk Kuatan", Jurnal: Jurnal Ilmiah Ekonomi dan Bisnis, vol. 12, No. 2, 2015.

Astutik, Puji “Pengaruh Tingkat Kesehatan Bank Menurut Risk Based Bank Rating Terhadap Kinerja Keuangan (Studi Pada Bank Umum Syariah Di Indonesia)",Jurnal: Fakultas Ekonomi Dan Bisnis Universitas Brawijaya.

Christiano, Mario. Tommy, Parengkuan. dan Saerang, Ivonne. “Analisis Terhadap Rasio-Rasio Keuangan Untuk Mengukur Profitabilitas Pada Bank-Bank Swasta Yang Go Public Di Bursa Efek Indonesia", Jurnal: Jurnal EMBA, ISSN 23031174, Vol. 2, No. 4, 2014

Dendawijaya, Lukman. Manajemen Perbankan. Jakarta: Ghalia Indonesia, 2005. 
Firmansyah, Irman." Determinant Of Non Performing Loan: The Case Of Islamic Bank In Indonesia", Buletin Ekonomi Moneter dan Perbankan, Bank Indonesia, Vol.17, No.2, 2014.

Ghazali, Imam. Aplikasi Analisis Multivariate Dengan Program IBM SPSS 21 (Semarang: Badan Penerbit Universitas Diponegoro, 2013.

Greuning, Hennie Van dan Iqbal, Zamir. Risk Analisis For Islamic Bank. Jakarta: Salemba Empat, 2011.

Hanafi, Mamduh M. dan Halim, Abdur. Analisis Laporan Keuangan. Yogyakarta: UPP STIM YKPN, 2014

Hermanto dan Saptuningsih,Endah. Electronic Data Processing SPSS 10 dan Eviews 3.0. Yogyakarta:UPFe UMY, 2002.

http://www.bi.go.id.

http://www.bps.go.id.

http://www.ojk.go.id.

Ismail, Manajemen Perbankan. Jakarta : Kencana Prenada Media Group, 2010.

Karim, Adiwarman A. Ekonomi Makro Islam. Jakarta: PT Raja Grafindo Persada, 2010.

Karim, Adiwarman A. Ekonomi Makro Islam. Jakarta: PT Raja Grafindo Persada, 2010.

Muh. Sabir dkk, "Pengaruh Rasio Kesehatan Bank Terhadap Kinerja Keuangan Bank Umum Syariah Dan Bank Konvensional Di Indonesia" Jurnal: Jurnal Analisis, ISSN 2303-1001, Vol. 1, No. 1, 2012.

Musjtari, Dewi Nurul dan Fitrianti, Fadia. Hukum Perbankan Syariah dan Takaful (Dalam Teori dan Praktek). Yogyakarta: Lab. Hukum UMY. 2010.

Nopirin. Ekonomi Moneter. Yogyakarta: BPFE Yogyakarta, 2009.

Peraturan Bank Indonesia(PBI) Nomor. 9/17/PBI/2007 Tentang Sistem Penilaian Tingkat Kesehatan Bank Perkreditan Rakyat Berdasarkan Prinsip Syariah. 
Rahmawati, Fajarwati dan Fauziyah, Statistika Teori dan Praktek, 2Statistika Teori dan Praktek. Yogyakarta: Prodi Manajemen Universitas Muhammadiyah Yogyakarta, 2014.

Rizal, Fitra. “Analisis Pengaruh Makroekonomi Terhadap Profitabilitas Perbankan Syariah Di Indonesia Periode 2005-2013". Skripsi, Universitas Muhammadiyah Yogyakarta, 2014.

Rizal, Fitra. “Pengaruh Capital Adequacy Ratio, Non Performing Finance dan Operational Expenses to Operational RevenueTerhadap Return on Assets Bank Pembiayaan Rakyat Syariah di Indonesia Periode 2012-2015", Jurnal Muslilm Heritage, Pascasarjana IAIN Ponorogo, 2017.

Sahara, Ayu Yunita. “Analisis Pengaruh Inflasi, Suku Bunga Bi Dan Produk Domestik Bruto Terhadap Return On Asset Bank Syariah di Indonesia". Jurnal Ilmu Manajemen Vol. 1, No. 1, 2013.

Sarwono, Jonathan. Metode Penelitian Kuantitatif dan Kualitatif. Yogyakarta: Graha Ilmu, 2006.

SEBI Nomor.9/29/DPbS/2007 Tentang Sistem Penilaian Tingkat Kesehatan BankPerkreditan Rakyat Berdasarkan Prinsip Syariah.

SEOJK Nomor 10/SEOJK.03/2014 Tentang Penilaian Tingkat Kesehatan Bank Umum Syariah Dan Unit Usaha Syariah.

Statistik Perbankan Syariah, 2015-2018.

Sugiono. Metode Penelitian Kuantitatif, Kualitatif dan R \& D. Bandung: Alfabeta, 2010.

Sukirno, Sadono. Makroekonomi Teori Pengantar. Jakarta: PT. Raja Grafindo, 2011.

Surat Edaran Otoritas Jasa Keuangan (SEOJK)Nomor 10/SEOJK.03/2014 Tentang Penilaian Tingkat Kesehatan Bank Umum Syariah dan Unit Usaha Syariah.

Tambunan, Tulus T.H. Perekonomian Indonesia Kajian Teoritis dan Analisis Empiris. Bogor: Ghalia Indonesia, 2012. 
Umam, Khaerul. Manajemen Perbankan Syariah (Bandung: Pustaka Setia, 2013.

Umiyati dan Ana, Leni Tantri. “Faktor-Faktor Yang Mempengaruhi Pembiayaan Pada Bank Umum Syariah Devisa Di Indonesia", Jurnal Ekonomi dan Perbankan Syariah, Vol. 5. No.1, April, 2017.

Undang-undang Nomor 21 tahun 2011 tentang Otoritas Jasa Keuangan (OJK).

Undang-undang Republik Indonesia Nomor 10 Tahun 1998 Tentang Perubahan Atas Undang-undang Nomor 7 Tahun 1992 Tentang Perbankan.

Undang-undang Republik Indonesia Nomor 21 Tahun 2008 Tentang Perbankan Syariah. 